This item was submitted to Loughborough's Research Repository by the author.

Items in Figshare are protected by copyright, with all rights reserved, unless otherwise indicated.

\title{
Is deliberative democracy feasible? Political disengagement and trust in liberal democratic states
}

\section{PLEASE CITE THE PUBLISHED VERSION}

http://dx.doi.org/10.1093/monist/onv021

\section{PUBLISHER}

(c) Oxford University Press/ Published on behalf of the Hegeler Institute

\section{VERSION}

AM (Accepted Manuscript)

\section{PUBLISHER STATEMENT}

This work is made available according to the conditions of the Creative Commons Attribution-NonCommercialNoDerivatives 4.0 International (CC BY-NC-ND 4.0) licence. Full details of this licence are available at: https://creativecommons.org/licenses/by-nc-nd/4.0/

\section{LICENCE}

CC BY-NC-ND 4.0

\section{REPOSITORY RECORD}

Parvin, Phil. 2015. "Is Deliberative Democracy Feasible? Political Disengagement and Trust in Liberal Democratic States”. Loughborough University. https://hdl.handle.net/2134/18059. 


\section{Is Deliberative Democracy Feasible? Political Disengagement and Trust in Liberal Democratic States*}

Liberal democratic states throughout the world are experiencing declining rates of political participation. Many political scientists and political philosophers have attributed this decline to an erosion of social capital: those bonds of reciprocity and trust which used to exist among citizens but which now, as a result of profound social, political, and cultural change, do not (e.g. Macedo et al, 2005; Putnam, 2001; Halpern, 2005; Whiteley, 2012).

Does deliberative democracy represent a feasible strategy for the reform of liberal democratic states experiencing declines in political participation? Looking at work on democracy among Anglo-American political philosophers over the past twenty years, it seems that the answer is 'yes' (e.g. Bohman, 2000; Cohen \& Sabel, 1997; Dryzek, 2000; Fung, 2004; Goodin, 2008; Gutmann \& Thompson, 1998 \& 2004; Mansbridge, 1999a; Mansbridge et al, 2012; Young, 2000). Deliberative democracy is held by many of its defenders as both a philosophically persuasive model of democracy which improves upon the traditional aggregative representative model and a feasible program for the reform of existing liberal democratic states (e.g. Bohman, 1998; Fishkin, 2011). Deliberative democrats argue that reconfiguring democracy as a process of 'public reasoning' among free and equal citizens can re-connect citizens with one another, and with the institutions which govern them, by resolving the wider challenge of diversity, and increasing the opportunities available to citizens to influence political decisions (Dryzek, 2012; Parkinson, 2012). Moral and political diversity can lead to fragmentation, conflict, and exclusion, so contemporary democracies need to ensure that the rules governing the process of policy formation and decision making are open, transparent, and encourage inclusion among all those who have a stake in the outcome (e.g. Bohman, 2000; Cohen, 2009; Fung \& Wright, 2003; Gutmann \& Thompson, 1998). Ensuring inclusion is crucial for democratic theory and practice. It is crucial for democratic theory because a regime which silences the voices of a proportion of its constituent members fails to ensure political equality. It is crucial for democratic practice because the 
systematic exclusion of citizen voices from democratic processes reinforces the separation of the people from the business of governance (Gutmann \& Thompson, 2004; Mansbridge, 1999b). The more that citizens feel peripheral to the democratic system, the less they see its activities as relevant to them and the less they understand it (Fishkin, 1991; Fung, 2004; Fung $\&$ Wright, 2003). Deliberative democrats argue that in emphasizing the need for collective deliberation among citizens on matters of policy and principle, their approach can ensure social unity and political stability in circumstances of diversity, produce democratically legitimate outcomes in the face of disagreement, and offer a response to democratic decline by reconnecting citizens with institutions and the regime of laws under which they live, and with one another (Benhabib, 1996; Chambers, 2009 \& 2012a; Dryzek, 2012; Parkinson, 2006). Thus, deliberation can solve fundamental problems experienced by actual liberal democratic states (Cohen, 1989; Fung, 2003; Fung \& Wright, 2004; Mansbridge, 2012; Parkinson, 2006 \& 2012; Postema, 1995; Rawls, 1995).

In contrast, I argue that deliberative democracy can represent a feasible strategy for democratic reform only if the role of deliberation is highly circumscribed. The more normative weight that is placed on the idea of deliberation, the more it is required to $d o$, the less politically feasible deliberative democracy becomes. This is because deliberative democrats assume and require widespread citizen participation in the democratic process but fail adequately to explain how this participation might be ensured in liberal democratic states characterized by historically low, and declining, levels of political engagement and social capital. Political disengagement among citizens is not just problematic for deliberative democracy, but all forms of democracy. But it is particularly problematic for deliberative democracy because it requires more of citizens than the traditional aggregative representative model: it does not merely seek to open up new opportunities for participation in democratic life, it requires that citizens take up these opportunities, or so I argue. This is controversial, as many defenders of deliberative democracy distinguish participation and deliberation, suggesting that a deliberative democracy need not require high levels of participation. However, I suggest that the vision of democratic life offered by deliberative democrats, which 
underpins their strategy for democratic reform, is of a system in which a significant proportion of the citizen population engage in the process of deliberation, and that this counts against the feasibility of deliberative democracy given the increasing unwillingness of citizens of existing liberal democratic states to participate in political life as a result of wider declines in social capital.

Given the importance of widespread citizen participation to deliberative democracy, it is important that deliberative democrats explain how they will ensure the requisite level and quality of deliberation in societies characterized by low levels of political engagement and participation, and it is problematic that they have not yet done so. It is possible to provide such an explanation. It is possible for liberal states to engage in trust-building initiatives aimed at developing the social capital necessary for increased participation. However, it is my intention in this piece to argue that such initiatives (a) would cause significant normative tensions with other aspects of Rawlsian deliberative democracy, and (b) would need to be independent of, and undertaken prior to, the establishment of deliberative democracy. I therefore argue that declining social capital and political participation weakens the case for deliberative democracy.

I distinguish between two broad approaches to deliberative democracy. I focus on a single but fundamental point of disagreement among deliberative democrats: should public reasoning be conceived as a process of deliberating on the substantive content of the parties' moral and ethical ideals, or as a minimalist process which aims at reaching agreements on matters of policy and principle on grounds which are independent of such substantive matters? This disagreement is driven partly by concerns about the political feasibility of the deliberative democratic model, which is my principal concern in this piece. Those who argue for a more minimalist conception of public reason do so in order that their theories can be more coherently applied in contemporary liberal democratic states characterized by profound disagreements over substantive moral questions. Those who defend a more substantive vision of deliberation argue that the minimalist approach presents an unnecessarily impoverished conception of public reason which is ill-equipped to resolve many of the most important 
questions which face contemporary democratic states. I suggest that neither approach is politically feasible. Both assume and require widespread citizen participation in democratic life that they are structurally ill-equipped to secure.

1. The minimalist approach.

Defenders of the minimalist approach understand deliberative democracy as grounded in a conception of public reason as a formal process of constrained discourse. The goal is to resolve 'fundamental questions' of justice as applied to the basic structure of society and the formal political sphere, rather than to the wider civic or 'non-political' realm. The most obvious exemplars of such a view are John Rawls and Joshua Cohen (Cohen, 1997 \& 1999; Rawls, 1993, 1997, \& 2001). Citizens who are motivated to reach agreement will, they argue, put aside their moral, philosophical, and religious differences and seek agreement on principles which can be justified independently of their conceptions of the good. Citizens will therefore submit to a norm of 'civility', understood as a willingness to modify the reasons they give for or against particular proposals, grounding them in principles which the other participants can reasonably agree to. Rawls and Cohen argue that such an exchange of 'public reasons' would lead participants to agree on a liberal constitutionalist regime grounded in liberal neutrality and the basic liberties common to liberalism.

Importantly, therefore, their conception of deliberative democracy is 'minimalist' in the relevant sense that it is a process of rational debate among free and equal citizens on political matters rather than substantive questions of morality, religion, or philosophical truth, but not in the sense that it contains no substantive vision of an ideal society. On the contrary, Cohen's and Rawls's theories are grounded in a vision of what a liberal democratic regime should look like, how citizens of such a regime should understand themselves and one another, and what the moral duties of citizens are with regard to one another. They then work backwards from this ideal and construct a model of public reason capable of delivering this vision: a conception of public reason as a rational dialogue among participants who exclude 
their own substantive religious and moral beliefs from the process and who instead appeal to wider, more general grounds for agreement acceptable to all.

However, Rawls is ambiguous on the question of whose activities should be regulated by the norms of public reason. While he is clear that norms of public reason should only be extended to the 'formal political sphere', it is not always clear what he takes this to mean. At points, he seems to suggest that he means the political sphere to describe a physical space inhabited by particular people who occupy particular social roles (Rawls, 1997, 133-134). However, he suggests at other points that the political sphere in fact describes a class of topics or issues and that anyone, including all citizens, should apply the norms of public reason to in their own deliberations on these issues (Rawls 1993, 212-247). On this latter view, norms of public reason should most obviously regulate the political deliberations of legislators and judges but there is nothing particularly special about these people other than they are more likely to spend more of their time engaging in public discussion of political issues than other citizens. If and when other citizens $d o$ engage in public discussion about political issues, they are, it seems, required to impose precisely the same constraints upon their deliberations. Citizens need not use public reason in their own private reflections and conversations. But they must when engaged in 'public advocacy' or when thinking about how to vote. The difference between a 'private conversation' and 'public advocacy', however, is left ambiguous.

Joshua Cohen is more explicit about both the need to understand the political sphere as a class of issues rather than a physical space, and about the need for widespread citizen participation in deliberation on political questions. Cohen's conception of a 'directly deliberative polyarchy' explicitly rejects the idea that public reason should be conceived as regulating only the activities of citizens who inhabit formal political institutions like legislatures and courts, calling instead for the creation of new and alternative forums of deliberation to the formal executive, legislative, and judicial branches of government (Cohen \& Sabel, 1997; Cohen 2009). In particular, his approach encourages deliberation among citizens through civil society 
associations in order that participants can draw on local knowledge in order to better identify and solve complex problems and improve governance (Cohen \& Rogers, 1995).

2. The substantive approach.

Defenders of the substantive approach call for a participatory form of politics in which as many citizens as possible engage in debates about political and moral questions, across and through civil society associations which act as mobilisers of public debate and engagement. This approach thus differs from the minimalist approach in that it explicitly invokes a conception of public reason as a process of resolving substantive moral disagreements among a wide number of citizens holding divergent comprehensive doctrines.

This approach has radical and less radical variants. The less radical group includes thinkers like Jane Mansbridge and Archon Fung and retains a support for liberal constitutionalism, albeit one which places a greater emphasis on citizen engagement than more traditional accounts (Chambers, 2009; Fung, 2004 \& 2015; Fung \& Wright, 2003; Mansbridge et al, 2012). It is this group who have been at the forefront of operationalizing the idea of deliberation in different political contexts and exploring ways in which ideal forms of deliberation might inform the resolution of real world policy dilemmas and encourage greater and richer forms of participation among citizens. Hence, Fung argues for the extension of norms of deliberation to institutions charged with the delivery of services such as education and policing, as well as greater use of 'mini-publics' in setting policy agendas (Fung, 2004). Similarly, Mansbridge has pioneered a 'systemic' approach in which norms of deliberation link and apply to the state, civil society organisations, corporations, and the media, as well as the 'everyday talk' of citizens (Mansbridge, 1999a; Mansbridge et al, 2012). Even informal sites of deliberation should 'be judged according to the same standards as classic deliberation in assemblies' (Mansbridge, 1999a, 213). Deliberation applies to the 'political sphere', but politics is defined in very broad terms as 'the medium through which human beings try to "make sense of their common situation through discourse with one another"' (Mansbridge, 
1999a, 216). It is thus wide in scope, and represents a space in which narrowly political as well as wider moral issues are appropriately discussed. But it is also substantive in depth because it is grounded in a more fluid, less restrictive conception of deliberation than that envisaged by the minimalists. Mansbridge et al hold that 'in both deliberative bodies and in the rest of the deliberative system, the concept of "public reason" should be enlarged to encompass a "considered mixture" of emotion and reason rather than pure rationality" (Mansbridge, 1999a, 213).

Some extend this vision. Drawing on critical theory and post-structuralist critiques of universal reason and liberal impartiality, they argue that deliberative democrats who invoke the conception of deliberation in the service of strengthening the liberal constitutionalist model merely offer a non-inclusive, partisan, and impoverished conception of deliberation which places too much power in the hands of elites (Dryzek, 2000 \& 2012; Young, 1995, 1996, \& 1999). What we need instead is a genuinely participatory form of democracy grounded in a substantive, free, and open dialogue among all relevantly affected citizens across multiple publics and social fora (Benhabib, 1996; Fraser, 1990 \& 1997). We need an inclusive system in which no citizens are barred from participating in the discourse as a result of pre-existing structural, social economic, or cultural factors, and which does not require that citizens squash themselves into a liberal mould that they find alien. No citizens should be barred entry from deliberation on the basis of their illiberal beliefs, and unlike in the theories of Rawls and Cohen (and also Gutmann \& Thompson and others), participants are not required to submit to some prior norm such as reciprocity or civility in order to gain entry to deliberation. Some emphasise the need for rational deliberation (where rationality is defined differently than it is by Rawls and Cohen, as the ability to justify and explain one's actions against a background of shared values rather than liberal neutrality) (Habermas, 1996 \& 1997). Others argue for the need to open up the deliberative process to alternative communicative strategies including rhetoric, emotion, storytelling, and - in face-to-face deliberation - non-linguistic gestures (Benhabib, 1996; Dryzek, 2000; Young, 2000). Doing so makes room for radical forms of discursive intervention across a wide range of deliberative fora. It produces a new and 
dynamic model of participatory democracy, in which citizens deliberate on the content of their substantive moral and political beliefs in a more open-ended, and less restrictive, way than in the minimalist approach.

3. Is minimalist deliberative democracy a viable strategy for reform?

Despite presenting a more circumscribed ideal of public reason, it is nevertheless clear that the minimalists' account of deliberative democracy requires citizens to participate (in appropriate ways) in the democratic system. Rawls, for example, argues that it is 'one of the political and social roots of democracy, and ... vital to its enduring strength and vigor' that citizens fulfill their 'duty of civility' toward others by not only voting, but also ensuring that their votes are informed by the ideal of public reason (Rawls, 1995, pp. 429-430). Adherence to the norms of public reason among judges, officials, and elected representatives who inhabit the physical political sphere is ensured by the wider citizenry holding them in check through their participation in political activities, in particular voting, and accepting norms of public reason in their own deliberations about political questions. Rawls thus argues that a just deliberative democracy requires that (a) citizens are sufficiently engaged as to participate in collective discussions about basic political questions, and that (b) they do so according to the norms of public reason.

Cohen is much more explicit about the importance of active citizen participation and about the fact that this participation should be regulated by the norms of a minimalist form of public reasoning. Deliberation for Cohen is a mechanism for gathering local knowledge, so citizens must actually contribute to this process. However, a democratic system which relies heavily on gathering epistemic insights from citizens is fundamentally compromised by political disengagement. The more democracy relies on citizens doing their bit, the more problematic it is when they do not. 
The minimalist approach thus requires citizen engagement in democratic life.

However, advocates of this approach do not explain how they will ensure participation. One might argue that Rawls does not need to provide such an explanation because his concern is to provide an idealized conception of deliberative democracy in its pure form. Rawls is indeed ambiguous on the question of whether his theory calls for the involvement of actual citizens in political deliberation. It is certainly possible to read his argument as an exercise in pure ideal theory. But doing so ignores the shift toward a more pragmatic approach in his later work. Moreover, Rawls is concerned that his theory be applicable in real-world political contexts and is keen to show that political feasibility is one of the strengths of his approach over Habermas's. One of the problems with Habermas's theory, Rawls argues, is that Habermas's ideal of communicative rationality is unrealistically demanding. 'Actual political conditions under which participants and other bodies conduct their business necessitate great departures from that ideal,' Rawls argues. There are pressures of time:

'discussions must ... in due course come to an end; votes must be taken. Not everyone can survey and evaluate all evidence and often it is too much even to read and understand. Legislators must not infrequently decide and vote in the dark, or else in accordance with what their not always impartial party leaders and constituents want (Rawls, 1993, 430).

Rawls argues that his ideal of deliberation, being more minimal than Habermas's, is more achievable in actual liberal democratic societies.

Rawls's position on whether the process of deliberation should be real or hypothetical is thus ambiguous. However, in so far as Rawls believes that his theory describes a feasible model of democracy that can be used to guide concrete reforms in the democratic practice of traditionally configured states, and in so far as he makes demands of citizens to actually act in particular ways, he is required to explain how the conditions necessary for this model to 
function might be established where they do not currently exist, and where citizens do not act in the ways he needs them to.

This is also true of Cohen, who is much clearer than Rawls on the importance of real world deliberation and political feasibility: the ideal of deliberation must be resilient to the challenges posed by the political reality of democratic life in complex liberal democratic states and it must present an achievable alternative to current democratic practice (e.g. Cohen, 1999). It is thus a crucial problem for Cohen and for Rawls (if he believes that his theory should be politically feasible) if citizens increasingly feel unwilling or unable to engage in the kind of activities that they require. If they want to offer a politically feasible conception of democracy which emphasizes the need for widespread citizen participation in the deliberative process, it is incumbent upon them to provide a more detailed explanation as to how their theories would ensure such participation among citizens exhibiting historically low levels of interest in politics. Political disengagement is one non-ideal form of pressure (like time and imperfect information) which a feasible normative conception of democracy must either resolve or make allowances for. Rawls and Cohen do neither.

Given the important role given to citizen participation by Rawls and Cohen, making allowances for its absence is not a viable option. Both Rawls and Cohen must explain how they will ensure the requisite level of appropriate participation among citizens for their theories of deliberative democracy to function. It is not clear that Rawls in particular can do so in a way that is consistent with his wider theory. He argues for a liberal constitutional order in which citizens have not only the formal right to participate but also the requisite social and economic resources to take advantage of that right: that the state protect not only the formal right to participate but the fair value of this right. Rawls is explicit about what is needed in order to secure the fair value of the basic liberty to participate: (a) the establishment of fair inequality via the difference principle, and (b) high levels of social capital. To be capable of participating in the minimalist forms of public reasoning required in a Rawlsian deliberative democracy, citizens must be freed from unfair inequalities. But they must also have developed 
the requisite skills and virtues of citizenship through their membership in civil society associations. For Rawls, as for Cohen, citizens learn how to be citizens, and how to deliberate appropriately, through their face to face interactions with others in civil society (Cohen, 1995; Rawls, 1971, 234 \& 1993, 212 - 354; Rawls, 1997).

These are demanding requirements which require a high degree of activity on the part of the state and of citizens to establish. If ensuring the fair value of the right to participate in a Rawlsian scheme requires both the alleviation of social and economic inequalities through the redistribution of wealth and resources from the most to the least advantaged and the establishment of high levels of social capital by creating a vibrant civil society populated by active citizens, then the requirements of a Rawlsian deliberative democracy require an expansion of the political into areas of life which Rawls believes should be considered 'nonpolitical', and a level of state activity in these areas which run counter to the wider vision of political liberalism. Rawlsian deliberative democracy requires citizen participation. Therefore, on Rawls's own terms, it requires the state to reduce inequality and to ensure a strong civic society comprised of associational groups capable of developing citizens' sense of citizenship, their own political competence, and their willingness to engage in appropriate forms of public reasoning and to submit to the duties of civility that democratic deliberation requires.

Empirical evidence on rates of participation in numerous liberal democratic states gathered over the past half-century supports this view. Increased inequality, deprivation, social fragmentation, and a weakening of traditional associational life in contemporary states has resulted in a weakening of common bonds of citizenship, and an erosion of precisely the kind of civil society that Rawls and other deliberative democrats rely on in their theories (Macedo et al, 2005; Putnam, 2001; Putnam et al, 2005; Stoker, 2006; Verba et al 1995; Whiteley, 2012). Some of the proposed causes for the decline in social capital, and civic and associational life, in the literature include the globalization of markets, the rise of a more fluid workforce, the decline of traditional manufacturing industries and the rise of the knowledge economy, the privatization of leisure, the rise of social and economic inequality, increased 
individualism, and the expansion of economic markets. These and numerous other factors have combined to destroy those opportunities for face to face contact that citizens once had with their neighbours, bosses, friends, extended families, and so on, leaving them isolated and alienated from one another, social capitalists argue. Furthermore, social inequalities have become increasingly entrenched, leading in many instances to cyclical deprivation and the $d e$ facto intergenerational disenfranchisement of entire demographic groups from the democratic system (Verba et al, 2003). If deliberative democracy requires a vibrant civil society, it must be created, or rather, recreated in the wake of these changes. Stocks of social capital have eroded and must be re-built; deprived neighborhoods lacking a civic and political infrastructure must be reformed; demographic inequalities must reduced; people who consider themselves divided or cut off from one another must be brought together. A social, political, and cultural shift must take place.

This is no small task, but a necessary one if deliberative democracy requires active and equal participation on the part of its citizens, as minimalists like Rawls and Cohen believe it does. The dialogue which Rawls and Cohen require may be minimal, but its requirements are not: it requires substantial social and economic planning, a strong civil society of associational groups capable of educating citizens in the complexities of the political issues at hand as well as the ability to deliberate about them appropriately, and a willingness among citizens to participate in the activities of these groups in order that they can engage in the appropriate forms of public reason and ensure the continued stability of the liberal constitutional order.

While Rawls and other deliberative democrats do argue for greater economic equality, the need to establish social capital is more problematic. They appear to assume that it is either unimportant or that it will simply emerge as a consequence of the deliberative process itself. But this assumption is neither born out by empirical evidence (as I will show in the next section) nor argued for in anything like enough detail. It is also not a politically feasible position, as will also become clearer in the next section. I suggest that one possible reason that this issue has received less attention than it should is that the decline in social capital among 
citizens of liberal democratic states is so acute and damaging, and its causes so manifold and complex, that rebuilding it would involve the state engaging in forms of political activity on a scale that would bring them into tension with the wider political liberal aim of restricting, rather than expanding, the realm of the political, and would require the state to ensure that citizens engage in forms of political activity that would further expand the realm of the political into areas of life that Rawls and other political liberals claim are off-limits. It would require, for example, that citizens actively participate in civil society associations and citizen groups, as such participation is important to the cultivation of social capital. It would require them to engage in volunteer work and to engage in the life of their local communities. It would require citizens to reach out to, and to socialize with, their neighbours and co-workers, and participate in numerous other social capital raising activities. It would, in short, require states and citizens to collaborate in the rebuilding of a society based on shared bonds of belonging and trust, and a thriving civic culture, that has all but disappeared in contemporary democratic states (Skocpol, 2004). Even if such a thing were possible, it would still run counter to the political liberal idea that states should not seek to interfere in the non-political lives of citizens. Deliberative democracy requires participation. Participation requires social capital. And social capital requires citizens to engage in certain forms of non-political behavior. Ensuring the fair value of the basic liberty to participate in democratic life thus requires interference in the nonpolitical lives of citizens in ways which bring it into direct conflict with the kind of political liberalism defended by Rawls, among others.

Furthermore, even if they did argue for the expansion of the political in this way, it is still not clear that Rawls, Cohen, and other minimalists could ensure the level of participation required. Indeed, viewed purely from the point of view of feasibility, the minimalist approach is unsuited to ensuring the kind of citizen participation that they require in the rates that they require. One of the most common reasons given by disengaged citizens for their unwillingness to engage in political life is the fact that the world of politics is separated from their own lives, and that political debates are removed from their own lived experience. Citizens claim to be alienated from the formal business of politics, and from the forms of dialogue which 
characterise and perpetuate it (e.g. Hansard Society \& Electoral Commission, 2012; Baston \& Ritchie, 2004; Parvin \& McHugh, 2005). Liberal democratic politics is conducted in a privileged and often ritualised language, and draws upon specialised vocabularies, concepts, and forms of knowledge which are common to that world alone. Consequently, the claim that we find in Rawls, Cohen et al that we should, in the interests of securing fairness and legitimacy, construct a purely political language which operates independently of the substantive commitments and lived experiences of individual citizens seems not so much a solution to the problem of political disengagement, but an argument for of one of its principal causes.

The vision of deliberative democracy that we find in Cohen, Rawls and other minimalists is thus problematic for two reasons. Firstly, the need to create the kind of civil society capable of increasing social capital and encouraging the necessary participation among citizens that is required by deliberative democracy violates political liberal neutrality. Secondly, the need to constrain one's deliberations by the norms of public reason exacerbates political disengagement.

4. Is substantive deliberative democracy a viable strategy for reform?

The substantive approach places even greater importance on the participation of citizens (and hence, on establishing the social, political, and civic conditions necessary for securing the fair value of the right to participate) than the minimalist approach because the legitimacy of laws are determined by a deliberative process framed by the shared values of the public revealed through public participation in a range of political activities, rather than the liberal principle of neutrality. In the absence of widespread citizen engagement, political institutions lose their anchor in the lived experiences of the people to whom they are accountable and become disconnected from public opinion. 
This is a particular problem for those more radical deliberative democrats whose theories are most obviously threatened by declines in engagement and, in particular, social capital. The deliberative process is, for thinkers like Dryzek and Young, a site of contestation characterized by protest and direct action in addition to more conventional forms of political reasoning. Participants deliberate from the perspective of their own lived experience and offer reasons for and against proposals in light of their own comprehensive beliefs. Consequently, deliberation in these theories is more charged and potentially unruly. Deliberation is a site of radical engagement with religious, moral, and philosophical ideals and a search for a genuinely inclusive political settlement, the terms of which are always subject to revision. The deliberative process, and the institutions and policies it produces, is open-ended and fluid.

This view relies more obviously on the need for high stocks of social capital and bonds of trust among citizens than even the minimalist approach. The more radical and contestatory the vision of deliberation, the more necessary it is for citizens to trust one another and the political institutions which regulate their political lives, and to have sufficient faith that their fellow deliberators are motivated to reach agreement (Miller, 1992). Deliberative democracy requires a willingness on the part of deliberators to look beyond the mere satisfaction of their own private interests and to construct a society in which all citizens might pursue their own interests within constraints justifiable to all, and it requires that participants have faith in the willingness of others to do this. Deliberators must be willing to look beyond mere preference-satisfaction to construct a society in which all citizens can pursue their own interests and must have reciprocal faith in the willingness of others. Deliberation requires social capital: a sense in each and every deliberator that they are engaged in a collective political endeavor with others, all of whom are motivated to reach agreements on matters of policy and principle which are acceptable to all on equal terms.

But, again, social capital is in decline in liberal democratic states (Macedo et al, 2005; Putnam, 2001; Stoker, 2005; Whiteley, 2012). Young and Dryzek assume and require the presence of high levels of social capital among citizens of liberal democratic states yet offer 
little guidance as to how it might be built when it is declining or non-existent. For substantivists it is a virtue of their approach that it avoids too many assumptions about citizens. It does not require people to share bonds of civility or mutual respect or even to have tolerant views with regard to those with whom they are deliberating (Dryzek, 2010; Mansbridge, 1999b). It does not require defenders of a pro-choice or a pro-life position on abortion to respect one another or their respective positions, for example, and neither does it require that disagreements of this kind be put aside. No-one is excluded from the deliberative process on the grounds that they do not meet some notional threshold of civility. Hence, public deliberation is likely to become rather 'uncivil', especially when substantive moral beliefs are being discussed. Mansbridge, for example, explicitly states that there is room for 'offensiveness, non-cooperation, and the threat of retaliation' in deliberative politics, even for 'raucous, angry, self-centered, bitter talk aiming at nothing but hurt' (Mansbridge, 1999a, 223). When participants are divided by such profound and potentially uncivil agreements about fundamental issues of personal morality, it is very important that they nevertheless feel united with their fellow deliberators - that they see them as fellow deliberators - on some other level or in some other way, in order for the deliberative enterprise to endure and produce the outcomes they require of it.

Recall, the point here is not whether Young, Dryzek et al present interesting claims about the nature of democracy at the level of ideal theory, but whether they offer compelling reasons in favour of reforming the current system of democracy along the lines they envisage. The question that faces us is: what would be the challenges to, and implications of, introducing reforms of the kind that deliberative democrats advocate into liberal democratic states as they are currently configured? There are numerous challenges but the principal one with which we have been concerned thus far, faced by substantivists and minimalists, is that actually existing states do not exhibit the level of political and civic trust or the level of participation that deliberative democracy requires to get going. When seeking to introduce reforms into an existing political arrangement, we must work with the existing arrangement with which we are presented, and in the case of contemporary democracies, this arrangement 
is characterized at least partly by widespread and increasing political disengagement of a kind that is incompatible with the form of politics that the deliberative democrats wish to establish.

At this point substantivists might propose one of two courses of action. The first might be to introduce the reforms anyway and do the best we can in imperfect circumstances until deliberation itself creates the trust necessary for a better functioning deliberative process. But this approach rests on the assumption that trust will emerge endogenously out of the process of deliberation itself. However, there is very little compelling evidence to support this assumption especially at the level of mass democracies comprising citizens divided by multiple and complex moral differences (Chambers, 2012). Indeed, there is a substantial empirical literature which suggests the opposite is true.

Recent studies suggest that civic and political activism is most common in homogenous societies and very uncommon in the kinds of divided societies that deliberative democrats describe. Deliberation does not build social capital and does not encourage participation (e.g. Conover \& Searing, 2005; Mutz, 2006; Ryfe, 2002). More deeply, the assumption that deliberation will itself encourage higher levels of participation produces an ironic tension at the heart of the radical substantivists' theories: the more they reject the liberal model of public reasoning for its exclusionary focus on rationality, the more they rely on something like liberal reason to produce agreements and create trust.

The assumption seems to be that if we abandon the liberal requirement that all citizens must deliberate according to universal standards of reason, in favour of a deliberative system in which citizens can engage in multiple forms of rational and non-rational political action, then the process of deliberation itself will promote trust and agreement. The irony of this view is that it requires a much more thoroughgoing optimism about the power of deliberation to resolve moral and political disagreements than is even held by those liberals that the substantivists criticize. As we saw in section 2, Rawls, Cohen et al argue that, in the end, citizens will voluntarily impose constraints on the way in which they deliberate having 
realized that deep moral conflicts cannot be resolved by rational debate. They also assume (problematically) that citizens will in fact do this because they are assumed to be motivated by the requisite norms of reasonableness, civility, and/or mutual respect. By dropping these assumptions, however, Young, Dryzek et al are forced to rely entirely on the activity of deliberation itself to create the levels of trust and community spirit necessary for citizens to arrive at mutually agreeable solutions to moral and political dilemmas. Substantivists like Dryzek want their theories to be politically achievable in actually existing democracies experiencing democratic decline. But if their theories are to represent a feasible normative response to democratic decline, they need to provide a clearer argument as to why we should assume that their accounts of deliberation would in fact build the trust necessary to produce consensus (or a 'metaconsensus') on moral and political matters (Dryzek, 2012). How could reforms aimed at establishing such a contestatory model possibly take hold in a political system characterized by political disengagement and a lack of trust?

A second approach might be to de-emphasize the need for widespread citizen participation and focus instead on improving the quality of deliberation among small groups of citizens, and increasing the influence of these groups in the wider decision-making process. This is an increasingly popular approach favoured by systems theorists like Mansbridge and Fung, as well as other supporters of the use of minipublics like Fishkin. For these thinkers, deliberation among citizens in minipublics can be used as proxies for wider deliberation among citizens more widely. The benefit of this approach is that one can harness the epistemic benefits of deliberation without having to worry about the messy business of ensuring widespread participation or trust. One can improve deliberation among small, select groups while leaving 'the rest of the population untouched' (Fishkin, 2009, 28).

This is the most feasible approach but it is so precisely because it significantly downplays the role of deliberation in democratic politics. Dryzek is less enthusiastic about the democratic potential of mini-publics than Mansbridge, Fung, and many others for precisely this reason (Dryzek, 2012). A deliberative democratic model focused on mini-publics is in 
many ways a rejection of the high-minded ideals shared by the deliberative democrats discussed in this piece: deliberation is not something that is expected or required among the citizenry at large, but rather something that small groups of hand-picked citizens do in order to help state officials make the right decisions in key areas of public policy. It does not envisage or require any significant change in the behavior of citizens, in their perception of themselves or others, or in their engagement with politics. It merely seeks to harness the epistemic benefits of small-group deliberation in the policy-making process. Consequently, while feasible, it could not represent an attractive or normatively consistent option for minimalists or substantivists, who as we have seen ground deliberative democracy in the need for appropriate and widespread participation in democratic life.

More recent work in systems theory has suggested that mini-publics and other deliberative fora might perform a more central role in binding a deliberative democracy together and capturing the diffuse political 'talk' which takes place across and between different parts of the system (Chambers, 2012b; Mansbridge et al, 2012; Parkinson, 2012). Such a view draws on the appeal of mini-publics and other discrete deliberative environments and uses them to ground a richer conception of democracy in which policies and decisions are shaped by the lived experiences of citizens in diverse and multiple contexts (Goodin, 2008; Niemeyer, 2014). As such, this more recent systemic conception of deliberative democracy looks a lot like the vision of deliberative democracy presented by other substantivists like Habermas, Benhabib, and Frazer who emphasise the need to include diverse forms of communication across 'multiple publics'. The problem remains, however, that the democratic innovations proposed by systems theorists and defenders of an expanded role for mini-publics are intended to capture forms of political talk which are declining in liberal democratic states. Citizens are increasingly disengaged from politics. The problem is not that existing democratic systems are incapable of incorporating political talk into the process of decision-making. It is that citizens are increasingly uninterested in engaging in political talk. Dryzek, for example, states that deliberative democracy should seek to include the insights provided by citizens in their political conversations in associations and political meetings, as well as in bars, 
restaurants, and so on (Dryzek, 2012). But, again, fewer and fewer citizens of liberal democratic states are engaging in political conversations in these or other contexts. Minipublics are a viable addition to democracy if their role and scope is limited. The bigger the role that mini-publics and other deliberative fora play in the theory, the more its defenders are required to explain (a) how they will ensure that citizens will engage in the kinds of political talk that these fora are designed to capture, and (b) what happens if this political talk is absent.

The key point is that both the minimalist and substantive approaches assume strong bonds of trust among citizens (and high levels of participation in deliberative activities) but have not adequately addressed the question of how this trust might be built where it does not exist. It is not impossible to provide such an explanation, or a theory as to how social capital might be rebuilt in order to facilitate a more deliberative form of democracy. Indeed, there is a substantial and growing literature on this topic (e.g. Macedo et al, 2005; Nelson et al, 2003; Putnam, 2001; Putnam et al, 2005). The point is that such trust-building strategies need to be outlined and must be exogenous to the deliberation. Even if deliberative democrats are right in assuming that social capital will be created by deliberation, they must still explain how a deliberative system can be introduced into an existing system in which the requisite levels of social capital necessary for the functioning of the deliberative system do not exist. Social capital is a pre-requisite of political participation. It needs to exist in advance of the introduction of deliberative reforms into existing liberal democratic regimes. As such, deliberative democrats need independent trust-building strategies in order to prepare the way for the introduction of deliberative reforms. But then it would be these trust-building strategies which are doing the work of democratic renewal, not deliberation. A more deliberative form of democracy cannot be pursued until these prior trust-building initiatives have succeeded in building an enduring sense of common citizenship and trust among citizens who are both divided by moral and religious beliefs and disengaged from the political system. While some philosophers may still consider deliberative democracy preferable to conventional liberal democracy, they could not do so on the grounds that it represents a strategy for the rebuilding of trust or the encouragement of political engagement among citizens. Deliberative democracy 
is not itself a strategy for rebuilding trust among citizens, and between citizens and states. The deliberative process requires bonds of trust.

\section{Conclusion.}

John Dryzek stated in 2000 that democratic theory at the eve of the $21^{\text {st }}$ century had taken 'a strong deliberative turn' (Dryzek, 2000, 1). In 2015, there are few signs of it turning back. The past two decades have seen deliberative democracy rise to a position of dominance as the preferred theory of democracy among Anglo-American political philosophers of a Rawlsian as well as a non-Rawlsian persuasion. These philosophers defend deliberative democracy as a philosophically persuasive alternative to the visions of democracy offered by elite theorists, social choice theorists, and defenders of an aggregative or majoritarian ideal. But they have also presented deliberative democracy as a feasible political corrective to the democratic malaise that has come to characterize many liberal democratic states.

I have argued that when judged as a feasible response to the democratic decline experienced by existing liberal democratic states, deliberative democracy remains at best under-theorised and at worst flawed. A deliberative democratic model my have strengths which render it a better response to certain political or social problems. And more deliberative forms of politics may produce better outcomes than non-deliberative ones. However, philosophers who argue for deliberative democracy as a feasible strategy for the reform of actually existing democratic states must contend with the dilemmas posed by those states. Contemporary liberal democratic states are characterized by low and declining levels of political participation and social capital. Citizens feel increasingly estranged from one another, from the institutions which govern them, and from the laws which emanate from these institutions. As a result, many citizens have disengaged from formal and informal forms of politics. Citizens cannot be relied upon to act in the ways that deliberative democrats require. 
Deliberative democrats have responded to this problem in three ways. Some have ignored it. Others have acknowledged it and, contrary to a growing body of empirical evidence, have argued that deliberation itself can rebuild bonds of trust necessary for widespread participation in politics. And others still have sought to avoid the issue by focusing on small scale deliberation within tightly controlled minipublics rather than citizens more widely. The first two approaches are philosophically and empirically inadequate. The third offers the greatest hope in terms of feasibility, but only by considerably downplaying the role of deliberation in deliberative democracy. I suggest, therefore, that deliberative democracy offers a vision of democratic politics which is either bold, distinctive and unfeasible, or feasible but not especially distinctive.

Bibliography

Baston L. \& K. Ritchie (2004) Turning Out or Turning Off? An Analysis of Political Disengagement and What Can Be Done About It (London: Electoral Reform Society).

Benhabib, S. (2002) The Claims of Culture: Equality and Diversity in a Global Era (Princeton, NJ: Princeton University Press).

(1996) 'Toward a Deliberative Model of Democratic Legitimacy', in Democracy and Difference: Contesting the Boundaries of the Political (Princeton, NJ: Princeton University Press), pp. 67 - 94.

Bohman, J. (1998) 'The Coming of Age of Deliberative Democracy', The Journal of Political Philosophy 6/4, pp. $400-425$.

(2000) Public Deliberation: Pluralism, Complexity, and Democracy (Cambridge, MA: MIT Press). 
Press).

Chambers, S. (2009) 'Rhetoric and the Public Sphere: Has Deliberative Democracy Abandoned Mass Democracy?', Political Theory 37, pp. 323 - 349.

(2012a) Public Reason and Deliberation (London: Routledge).

-(2012b) 'Deliberation in Mass Democracy,' in J. Mansbridge \& J. Parkinson (eds)

Deliberative Systems, pp. 52-71.

Cohen, J. (1997) 'Deliberation and Democratic Legitimacy', in J. Bohman \& W. Rehg (eds) Deliberative Democracy: Essays on Reason and Politics (Cambridge, MA: MIT Press), pp. 67 $-92$. (1999) 'Reflections on Habermas on Democracy', Ratio Juris 12/4, pp. 385-416. (2009) Philosophy, Politics, Democracy: Selected Essays (Cambridge, MA: Harvard University Press).

Cohen, J. \& C. Sabel (1997) 'Directly-Deliberative Polyarchy', European Law Journal 3/4, pp. 313-342.

Cohen, J. \& J. Rogers (1995) Associations and Democracy (London: Verso).

Dryzek, J. (2000) Deliberative Democracy and Beyond: Liberals, Critics, Contestations (Oxford: Oxford University Press). 
(Cambridge: Polity).

(2012) Foundations and Frontiers of Deliberative Governance (Oxford: Oxford

University Press).

Estlund, D. (2009) Democratic Authority: A Philosophical Framework (Princeton, NJ:

Princeton University Press).

Fishkin, J. (1991) Democracy and Deliberation: New Directions for Democratic Reform (New Haven: Yale University Press).

Fraser, N. (1990) 'Rethinking the Public Sphere: A Contribution to the Critique of Actually Existing Democracies', Social Text 25/26, pp. 56-80.

(1997) Justice Interruptus: Critical Reflections on the 'Post-Socialist' Condition

(London: Routledge)

Fung, A. (2004) Empowered Participation: Reinventing Urban Democracy (Princeton, NJ:

Princeton University Press).

--------- (2015) 'Putting the Public Back in to Governance: The Challenges of Citizen

Participation and its Future,' Public Administration Review 25, pp. 1-10.

Fung, A. \& E. Wright (2003) Deepening Democracy: Institutional Innovations in Empowered Participatory Governance (London: Verso).

Goodin, B. (2008) Innovating Democracy: Democratic Theory and Practice After the Deliberative Turn (Oxford: Oxford University Press). 
Gutmann, A. \& D. Thompson (1998) Democracy and Disagreement (Cambridge, MA:

Harvard University Press).

(2002) 'Deliberative Democracy Beyond Process' Journal of Political Philosophy 10: 153-164.

(2004) Why Deliberative Democracy? (Princeton, NJ: Princeton University Press).

Habermas, J. (1996) 'Three Normative Models of Democracy', in S. Benhabib (ed) Difference and Democracy.

(1997) Between Facts and Norms: Contributions to a Discourse Theory of Law and

Democracy, W. Rehg (trans) (Cambridge, MA: MIT Press).

Halpern, D. (2005) Social Capital (Cambridge: Polity).

Hansard Society \& Electoral Commission (2012) An Audit of Political Engagement 9 (London: Hansard Society).

Macedo, S. et al (2005) Democracy at Risk: How Political Choices Undermine Citizen Participation, and What We Can Do About It (Washington DC: Broomings Institution).

Mansbridge, J. (1999a) 'Everyday talk in Deliberative System', in S. Macedo (ed)

Deliberative Politics: Essays on Democracy and Disagreement (Oxford: Oxford University Press), pp. 211-239. 
(1999b) 'On the Idea that Participation Makes Better Citizens', S. L. Elkin \& K. E.

Soltan (eds) Citizen Comptenence and Democratic Institutions (University Park: Penn State University Press).

Mansbridge, J., J. Bohman, S. Chambers, T. Christiano, A. Fung, J. Parkinson, D. Thompson, \& M. E. Warren (2012) 'A Systemic Approach to Deliberative Democracy’, J. Parkinson \& J. Mansbridge (eds.) Deliberative Systems (Cambridge: Cambridge University Press, 2012), pp. $1-26$

Miller, D. (1992) 'Deliberative Democracy and Social Choice', Political Studies, Special Issue, pp. 54-67.

Mutz, D. C. (2006) Hearing the Other Side: Deliberative versus Participatory Democracy (Cambridge: Cambridge University Press).

Nelson, B. J., L. Kaboolian, \& K. A. Carver (2003) How to Build Social Capital Across Communities (Los Angeles: The Concordia Project).

Niemeyer, S. (2014) 'Scaling Up Deliberation to Mass Publics: Harnessing Mini-Publics in a Deliberative System', in K. Gronlund, A. Bachtiger, \& M. Setala (eds) Deliberative MiniPublics: Involving Citizens in the Democratic Process (Wivenhoe: ECPR Press).

Parkinson, J. (2006) Deliberating in the Real World: Problems of Legitimacy in Deliberative Democracy (Oxford: Oxford University Press).

--------- (2012) ‘Democratizing Deliberative Systems', in Parkinson \& Mansbridge (eds) Deliberative Systems, pp. 151-172. 
Parvin, P. \& D. McHugh (2005) 'Defending Representative Democracy: Political Parties and the Future of Political Engagement in the UK', Parliamentary Affairs 58/3, pp. $632-655$.

Pateman, C. (1970) Participation and Democratic Theory (Cambridge: Cambridge University Press).

Postema, G. J. (1995) 'Public Practical Discourse: Political Practice', in I. Shapiro \& J. Wagner (eds) NOMOS XXVII: Theory and Practice (New York: New York University Press), pp. 345-385.

Putnam, R. D. (2001) Bowling Alone: The Collapse and Revival of American Community (New York: Simon \& Schuster).

Putnam, R. D., L. M. Feldstein \& D. Cohen (2005) Better Together: Restoring the American Community (New York: Simon \& Schuster).

Rawls, J. (1971) A Theory of Justice (New York: Oxford University Press)

Rawls, J. (1993) Political Liberalism (New York: Columbia University Press). - (1997) 'The Idea of Public Reason Re-Visited', in S. Freeman (ed.) John Rawls: Collected Papers (Cambridge, MA: Harvard university Press, 1999), pp. 573-615. (2001) Justice as Fairness: A Re-Statement (Cambridge, MA: Harvard University Press).

Ryfe, D. M. (2002) 'The Practice of Deliberative Democracy: A Study of 16 Deliberative Organisations', Political Communication 19, pp. 359-377. 
Skocpol, T. \& Morris P. Fiorina (eds.) (1999) Civic Engagement in American Democracy (Washington D.C: Brookings Institution).

Skocpol, T. (2004) 'Voice and Equality: The Transformation of American Civic Democracy', Perspectives on Politics 2/4, pp. 3-20.

Stoker, G. (2006) Why Politics Matters: Making Democracy Work (Basingstoke: Palgrave Macmillan).

Urbinati, N. \& M. E. Warren (2008) 'The Concept of Representation in Contemporary Democratic Theory', Annual Review of Political Science 11, pp. 387-412.

Verba, S., K. L. Schlozman, \& H. Brady (1995) Voice and Equality: Civic Voluntarism in American Politics (Cambridge, MA: Harvard University Press).

Verba, S., N. Burns, \& K. L. Schlozman (2003) 'Unequal at the Starting Line: Creating Participatory Inequalities Across Generations and Among Groups', The American Sociologist 34, pp. 45-69.

Whiteley, P. (2012) Political Participation in Britain: The Decline and Revival of Civic Culture (Basingstoke: Palgrave Macmillan).

Young, I. M. (1995) 'Rawls's Political Liberalism', Journal of Political Philosophy 3/2 181 190.

--------- (1999) ‘Justice, Inclusion, and Deliberative Democracy', S. Macedo (ed.)

Deliberative Politics: Essays on Democracy and Disagreement (OUP, 1999). 
* I would like to thank the participants of the Cambridge Political Philosophy Workshop and the two anonymous referees for The Monist for their help in improving this piece. I would particularly like to thank Clare Chambers who commented on several drafts. 